STUDI

FRANCESI

\section{Studi Francesi}

Rivista quadrimestrale fondata da Franco Simone

174 (LVIII | III) | 2014

Varia

\title{
Luc Fraisse, Nerval et le roman dogmatique et Proust romancier lecteur de Vigny
}

\section{Lise Sabourin}

\section{(2) OpenEdition}

10 Journals

\section{Édition électronique}

URL : http://journals.openedition.org/studifrancesi/1573

DOI : 10.4000/studifrancesi. 1573

ISSN : 2421-5856

Éditeur

Rosenberg \& Sellier

\section{Édition imprimée}

Date de publication : 1 novembre 2014

Pagination : 621-622

ISSN : 0039-2944

\section{Référence électronique}

Lise Sabourin, "Luc Fraisse, Nerval et le roman dogmatique et Proust romancier lecteur de Vigny », Studi Francesi [En ligne], 174 (LVIII | III) | 2014, mis en ligne le 01 novembre 2014, consulté le 18 septembre 2020. URL : http://journals.openedition.org/studifrancesi/1573 ; DOI : https://doi.org/10.4000/

studifrancesi. 1573

Ce document a été généré automatiquement le 18 septembre 2020.

\section{(c)}

Studi Francesi è distribuita con Licenza Creative Commons Attribuzione - Non commerciale - Non opere derivate 4.0 Internazionale. 


\title{
Luc Fraisse, Nerval et le roman dogmatique et Proust romancier lecteur de Vigny
}

\author{
Lise Sabourin
}

\section{RÉFÉRENCE}

LUC FRAISSE, Nerval et le roman dogmatique et Proust romancier lecteur de Vigny, in La Petite Musique du style, Proust et ses sources littéraires, Paris, Classiques Garnier, 2011, pp.

249-264 et 265-290.

1 Dans ce volume regroupant nombre d'articles écrits par le grand spécialiste des sources littéraires de Proust (comme philosophiques d'ailleurs, ainsi que l'a prouvé depuis son monumental livre sur L'Éclectisme philosophique de Proust, P.U. Paris-Sorbonne, 2013), signalons deux articles sur Nerval et Vigny (reprenant et remaniant leurs premières versions parues respectivement dans Romanistiche Zeitschrift für Literaturgeschichte de l'Université d'Heidelberg, hiver 2008, n. 32, pp. 71-81 et dans Studi di Letteratura francese, t. XXXVII, 2003, pp. 115-139), ces deux auteurs romantiques ayant légué quelques perles de pensée poétique au grand romancier.

2 Nerval a participé de la genèse secrète de La Recherche dès 1908, la structure narrative et les thématiques de «Sylvie» ayant laissé planer sur «Combray», mais aussi sur Le Temps retrouvé sa pensée sur la condition d'artiste: peintre, compositeur et écrivain connaissent également les trois âges de la création (illusions d'enfance, désillusions de la maturité, révélation de l'art). Le récit onirique de Nerval se revivifie dans le roman de la «mémoire involontaire» proustien, par la dilatation du temps et de l'espace en une trame continue qui n'exclut pas les intermittences du cœur.

Vigny, quant à lui, a inspiré par certaines de ses formules poétiques, maintes fois relues, les germes d'épisodes essentiels, tels les «détours imprévus» de «La Maison du berger» sur les chemins de Swann ou les invectives de «La Colère de Samson» dans la 
malédiction attachée à Sodome et Gomorrhe. D'ailleurs ses vers sont parfois mis en exergue, et le motif du diamant convient bien au «doux chantre» qu'est Bergotte. Ainsi Luc Fraisse nous entraîne-t-il dans l'atelier intérieur qui prépare l'avènement de l'œuvre. 